Chirurgia (2018) 113: 486-496

No. 4, July - August

Copyright@ Celsius

http://dx.doi.org/10.21614/chirurgia.113.4.486

\title{
New Options in the Management of Cystic Echinococcosis - A Single Centre Experience Using Minimally Invasive Techniques
}

\author{
Alexandru Cosmin Popa ${ }^{1,2}$, Okan Akhann ${ }^{3}$, Marius Septimiu Petruțescu' ${ }^{1}$, Loredana Gabriela Popa ${ }^{1,2}$, \\ Corina Constantin ${ }^{1}$, Patricia Mihăilescu ${ }^{1}$, Carmen Michaela Crețu, ${ }^{1,2}$, Cristian Botezatu' ${ }^{2}$, Bogdan Mastalier ${ }^{1,2}$ \\ 1"Colentina" Teaching Hospital, C.D.P.C., Bucharest, Romania \\ 2"Carol Davila" University of Medicine and Pharmacy Bucharest, Romania \\ 3"Hacettepe" University, Faculty of Medicine, Ankara, Turkey
}

Corresponding author:

Botezatu Cristian, assistant professor,

"Carol Davila" University of Medicine and Pharmacy Bucharest, Romani

"Colentina" Teaching Hospital -

C.D.P.C., Bucharest

E-mail: cristi_botezatu2001@yahoo.com

\section{Rezumat}

Optiuni noi în managementul echinococozei chistice - experienta unui singur centru în utilizarea tehnicilor de abord minim invasiv

Obiectiv: Scopul acestui studiu este de a verifica dacă experiența pe 4 ani în utilizarea tehnicilor de abord minim invaziv în tratamentul echinococozei chistice (CE) se potriveşte ca indicații şi rezultate cu studiile importante pe această temă.

Metodă: În perioada 03.2014 - 03. 2018, 38 PAIR, 28 proceduri MoCaT (cateterizare modificată) şi 7 drenaje percutanate au fost efectuate la 51 pacienți din 76 cazuri de chisturi hidatice hepatice (67,1\%). Lotul a cuprins 26 bărbați şi 25 de femei, iar vârsta a fost între 19 şi 78 de ani. 7 pacienți au avut 2 sau mai multe chisturi hidatice şi câte 2 proceduri au fost efectuate la 3 dintre aceştia; alți 11 pacienți au necesitat o a doua procedurăpe parcursul supravegherii.

Rezultate: Evoluția pacienților a fost bună, iar supravegherea acestora a fost de minim 2 ani. $\mathrm{Nu}$ au existat efecte majore de natură chirurgicală. Am definit ca rezultat bun obținerea unei cicatrici sau a unei mici cavități cu pereți calcificați (hiperecogeni). Doar $2(3,9 \%)$ pacienți au necesitat conversia la chirurgie deschisă. Complicatiile întâlnite au fost fistulele chisto-biliare în 15 cazuri $(29,4 \%)$ şi redeschiderea cavitătii în 11 cazuri $(21,67 \%)$.

Concluzii: Metodele de tratament percutan pentru CE sunt sigure şi eficace, dacă se respectă utilizarea lor în funcție de tipul chistului. Tratamentul percutan este o alternativă mai uşoară la chirurgia 
deschisă şi are rate mai scăzute de complicații şi recăderi, precum şi o spitalizare mai scurtă. Acum tratament de rutină, devine încet prima opțiune în abordul invaziv al CE. Rolul chirurgiei deschise este redus la $\mathrm{CE}$ cu complicații severe.

Cuvinte cheie: chist hidatic, tehnici minim invazive, PAIR, Mo-CAT, drenaj percutanat, cavitate reziduală

\section{Abstract}

Objective: The aim of this study is to verify if the experience on 4 years in using minimally invasive techniques in the treatment of $\mathrm{CE}$ could match regarding the indications and results with the major studies on topic.

Method: During 03.2014 - 03. 2018 period, 38 PAIR, 28 MoCaT procedures and 7 percutaneous drainages have been performed at 51 patients from 76 cases of hydatid hepatic cysts $(67,1 \%)$. There were 26 men and 25 women, and the age ranged from 19 to 78.7 patients have had 2 hydatid hepatic cysts or more and 2 procedures were performed at 3 of those patients; other 11 patients needed the second procedure during the surveillance.

Results: The evolution of the patients was favorable, and the surveillance was 2 years postintervention at least. There were no major surgical adverse effects. We defined as an expected result obtaining a scar lesion or a small cavity with calcified walls (hyperechoic). Only 2 (3,9\%) patients needed conversion to open surgery. The complications we have faced were represented by the cystic-biliary fistula in 15 cases $(29,4 \%)$ and the re-opening of the cyst's cavity in 11 cases $(21,67 \%)$. Conclusions: The percutaneous treatment of $\mathrm{CE}$ is safe and effective, following the correct assignation according with the cysts' type. The percutaneous treatment of $\mathrm{CE}$ is an easier alternative to the open surgery and has lower rate of complications and relapses, and a shorter hospitalisation. Now routine, it becomes slighty the first option for invasive treatment of $\mathrm{CE}$. The role of open surgery is restricted to $\mathrm{CE}$ with severe complications.

Key words: hydatic cyst, minimally invasive techniques, PAIR, Mo-CAT, percutaneous drainage, residual cavity

\section{Background}

Human echinococcosis is a severe zoonosis caused by Echinococcus (E.) tapeworms carried in the small intestine of carnivores, being larval forms (metacestodes). Among those species, two are often seen in the medical practice - E. granulosus and E. multilocularis - causing cystic echinococcosis (CE) and alveolar echinococcosis (AE), respectively.

Human $\mathrm{CE}$ is highly endemic in large regions of Mediterranean area, Eastern Europe, South America, the Near and Middle East, East Africa, Central Asia, Australia, New Zealand, China and Russia,. In Romania, over 1000 new cases of $\mathrm{CE}$ are found every year.

Almost any organ could be affected in CE by metacestodes - the larval forms of the parasite. The main involved organs are the liver $(75 \%)$ and the lungs (5-15\%), followed by spleen, brain, heart, kidneys, muscles, bones (1).

\section{CE Diagnosis}

\section{Clinical findings}

After an undefined and variable incubation period, CE may become symptomatic if active cysts exert pressure on adjacent tissue or induce other pathologic events $(1,2)$. The liver is the most common location for cysts to develop (69-75\%). The development of a cyst is slow and usually without specific clinical manifestations. However, mechanical, toxic or 
septic effects can result in complications (21\%). In general, clinical manifestations associated with liver cysts are divers, with patients presenting with abdominal pain, dyspepsia, fever or allergic manifestations, including a rash. Rupture to the biliary tree is a common occurrence $(1,3,4)$, presenting with signs of cholangitis and/or bile duct obstruction (5).

\section{Serology}

Obviously, nor the intradermic reaction Cassoni is no longer used, neither complement reaction.

Sensitivity is variable: between 85 and $98 \%$ for liver cysts, $50-60 \%$ for lung cysts and 90-100\% for multiple organ cysts with different locations, if serum antibody detection is the main method of serological diagnosis using indirect hemagglutination, ELISA, or latex agglutination, with hydatid cyst fluid antigens (6-9). Specificity of those tests is limited by cross-reactions due to other cestode infections (Taenia solium), some other helminth diseases, liver cirrhosis, malignancies, and presence of anti-P1 antibodies. In those dubious cases, confirmatory tests should be used (arc -5 test; Antigen B (AgB) $8 \mathrm{kDa} / 12 \mathrm{kDa}$ subunits or EgAgB8/1 immunoblotting) (6-8). Immunoblotting is best for differential diagnosis and may be used as a first-line test (10). There is no significant diagnostic advantage using detection of parasite-specific IgE or IgG4. Eosinophil count, IgE and IgG4 are more elevated after rupture/leakage of cysts $(6,11)$.

\section{Imaging}

US examination is the basic imagery technique in $\mathrm{CE}$ diagnosis for every abdominal locations, and could visualize cysts in other extraabdominal locations: smooth tissues, heart, even lung for peripheral cysts.

In 1995, the WHO-IWGE developed a standardised classification that should be applied, and allow a natural grouping of the cysts into three relevant groups: active (CE1 and 2), transitional (CE3) and inactive (CE4 and 5) (12). WHO-IWGE classification is the basis for the present guidelines; it differs from Gharbi's classification introduced in 1981 (13) by adding a "cystic lesion" (CL) stage (undifferentiated), and by reversing the order of $\mathrm{CE}$ Types 2 and 3. CE3 transitional cysts may be differentiated into CE3a (with detached endocyst) and CE3b (predominantly solid with daughter vesicles) (14). CE1 and CE3a are early stages and CE4 and CE5 late stages (Fig. 1).

Thoracic and bone involvement can be easily diagnosed using conventional X-ray exams.

Computed tomography (CT), and magnetic resonance (MR) imaging, with one T2-weighted imaging sequence are indicated in several particular presentations of CE: (1)subdiaphragmatic location, (2) disseminated disease, (3) extraabdominal location, (4) abscess and (5) pre-surgical evaluation. If possible cholangiopancreatography (MRCP) is needed in complicated cysts (abscess, cysto-biliary fistulae). MR imaging has better visualization of liquid

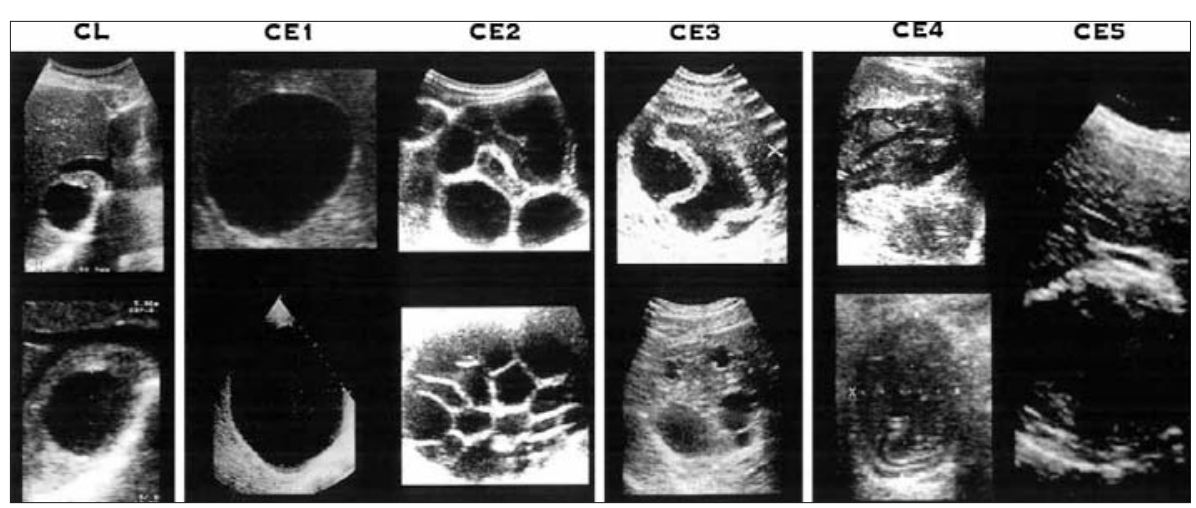

Figure 1. Ultrasonographic (US) appearance of CE according WHO-IWGE standardized classification 


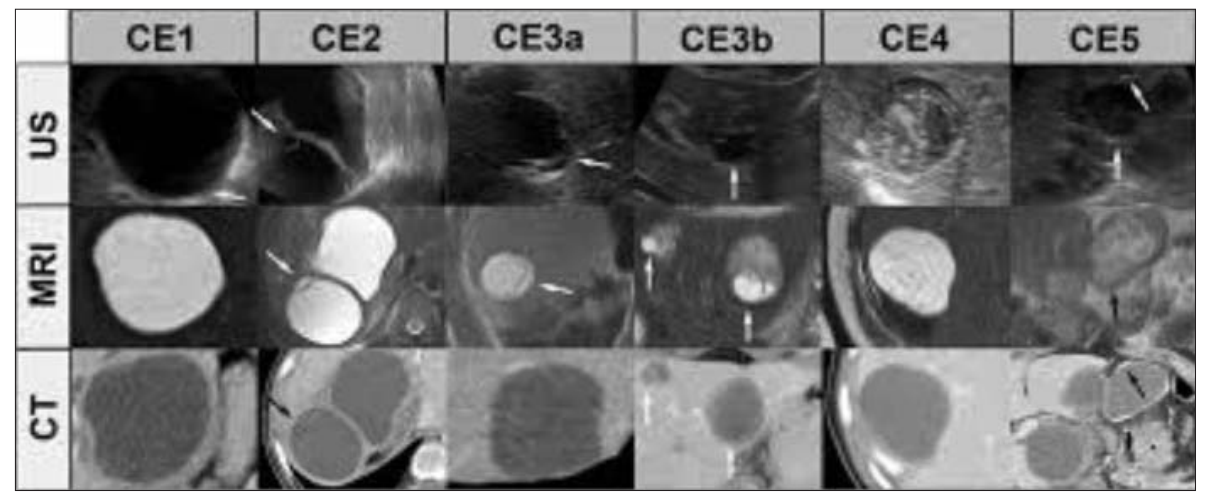

Figure 2. US, MRI and CT appearance of CE using WHO-IWGE Classification

areas within the matrix than $\mathrm{CT}(6,15)$ (Fig. 2). ERCP with or without sphyncterotomy (ES) is a valuable technique especially for the cysts opened into the biliary tree.

\section{Treatment Principles}

Nobody can claim a "best" treatment option for CE. Furthermore, there is no clinical trial which analysed all the different treatment modalities, including "Watch and Wait." Treatment indications are based on cyst characteristics (size, location, number, stage, complications), patient-related criteria (age, pregnancy, other pathologies, therapeutic risks, compliance of patients to long-term monitoring), available medical/surgical experience and equipment. Practically, it becomes a stagespecific approach, and could be complex (6).

Classically, albendazol $800 \mathrm{mg}$ daily remains the basic treatment for $\mathrm{CE}$, which is the start of every therapeutic approach, except the major emergency cases. The surgical treatment is preferred for large cysts (over $5 \mathrm{~cm}$ in diameter) or non-responsive cysts. After surgery, albendazole is carried on for at least 1 month $(16,17)$.

The minimally invasive treatment for $\mathrm{CE}$ is one of the options of the WHO-Informal Working Group on CE (WHO-IWGE) state-ofarts on Cystic Echinococcosis, becoming the first option of treatment since 2015. PAIR (Puncture, Aspiration, Injection, Re-Aspiration) is widely used now as treatment for hydatic hepatic cysts type CE1 and CE3a according WHO-IWGE clasification, larger than $5 \mathrm{~cm}$. It was proposed in 1986 by a tunisian team leaded by
Ben-Amor (18) and spred in 90 by Filice and Brunetti (19) in Italy. Placing a catheter at the end of the procedure (PAIR-D) is recomended for larger cysts. Akhan, in Turkey, has developed a new technique increasing the catheter's diameter and setting it under fluoroscopic control (MoCaT), using also a sustained lavage with $\mathrm{NaCl} 0,9 \%$; after the complete evacuation of the cyst, verifying there is no biliary fistula, the cavity is washed for $7 \mathrm{~min}$. with $96^{\circ}$ alcohol; he recomends this method for type CE2 and CE3b cysts (20). Prophylaxis with ABZ $4 \mathrm{~h}$ before and 1 month after PAIR is mandatory (21).

The risks of these minimally invasive techniques are the same as the risks of every punctioning procedure (bleeding, infection, damage of the tissues), and those specific for $\mathrm{CE}$ :

- Anaphylactic shock or allergic reactions;

- Spillage of the cystic content;

- Too fast evacuation of the cyst may lead to open the biliary fistulae;

- Persistence of the daughter-vesiculae due to the incomplete evacuation or incorrect check-up of the procedure, which may lead to relapse;

- Sclerosing colangitis if the parasiticid compunds ( $96 \%$ alcohol) is used when the biliary fistula exist;

- Systemic toxicity of 96\% alcohol or even $\mathrm{NaCl} 30 \%$ if the used amount is large (giant cysts) (22).

\section{Material and Methods}

The General Surgery Clinic of the „Colentina” 
Teaching Hospital has implemented this minimally invasive techniques in treatment of $\mathrm{CE}$ in partnership with Hacettepe University from Ankara - Prof. Akhan O., as a part of the European Project FP7 HERACLES, dedicated to the hydatid disease.

The criteria to asign a patient for a minimally invasive treatment are:

- Cyst - related criteria:

1. size: cysts over $5 \mathrm{~cm}$ in diameter;

2. cyst staging: CL, CE1, CE3a cysts benefit by PAIR technique; CE2, CE3b, selected cases of CE3a and CE4 benefit by MoCaT technique;

3. multiple cysts: they could benefit of those techniques;

4. infected cysts, abscesses derived from CE: MoCaT;

- Patient - related criteria:

1. pregnancy;

2. non-responsive patients to the albendazol treatment;

3. patients to whom the open surgical procedures could not be applied;

4. post-operative relapses;

5. patients who refuse open surgery, but need an invasive procedure.

Obviously, there are some contraindications as following:

- Non-cooperating patients;

- Cerebral, cardiac, medullar CE;

- Inactive / calcified cysts;

- Rupture of the cysts into peritoneal cavity, urinary tract, bronchiae;

- Cysts opened into the biliary tree (only for PAIR technique).

During 03.2014-03. 2018 period, 38 PAIR,
$28 \mathrm{MoCaT}$ procedures and 7 percutaneous drainages have been performed at 51 patients from 76 cases of hydatid hepatic cysts $(67,1 \%)$. There were 26 men and 25 women, and the age ranged from 19 to 78 .

7 patients have had 2 hydatid hepatic cysts or more and 2 procedures were performed at 3 of those patients; other 11 patients needed the second procedure during the surveillance. We performed 2 or more PAIR procedures on the same patient, if he had 2 or more CE1 cysts. If the cysts were in various stages (CE1 and 2, $3 \mathrm{a}, 3 \mathrm{~b}$ ), we performed PAIR and MoCaT in the same session. We didn't perform 2 MoCaT procedures at the same patient, nor in the same session, neither in seriated sessions.

Most of the cysts were found in the VII ${ }^{\text {th }}, \mathrm{V}^{\text {th }}$ and III ${ }^{\text {rd }}$ hepatic segments $(14,11$ and 10 cysts respectively), followed IVB, VI and VIII segments. There was no preffered type of cysts according the location (Graphic 1).

According the stage of the cyst, we have found CE1 and CE3b type cysts mainly (29 and 20 cases respectively), followed by CE3a type cysts in a smaller number ( 7 cases). CE2, CE4 type cysts and CL were few in number (Graphic 2).

We used PAIR technique (Punction, Aspiration, Inactivation, Reaspiration) especially for CE1 type cysts, and very rare for CE3a type cysts (Figs. 3-7). We used CHIBA needles, 18G, $15 \mathrm{~cm}$ long. The cysts were punctured under ultrasound guidance, using regular ultrasound devices with $3,5 \mathrm{MHz}$ convexe probes. Over $50 \%$ of the hydatid liquid is aspirated, then ultrasound compound is injected and the fluoroscopic control

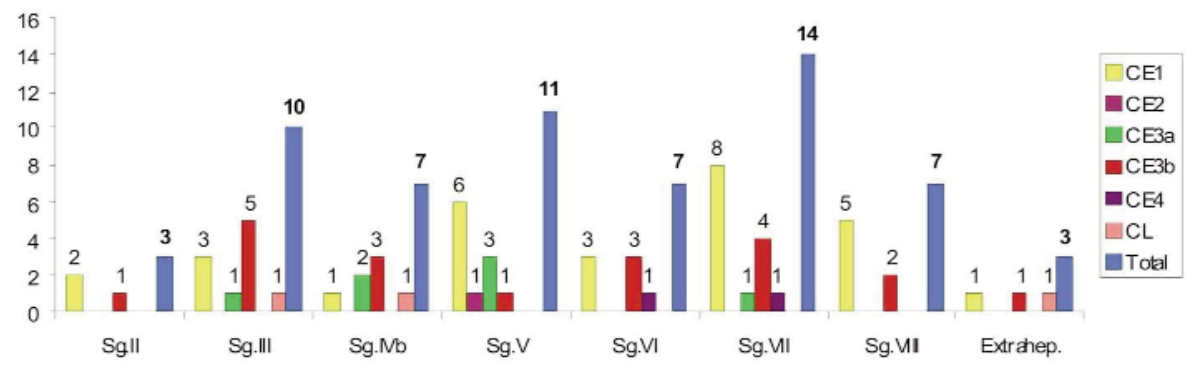

Graphic 1. Cysts distribution after the evolution stage, following the location 


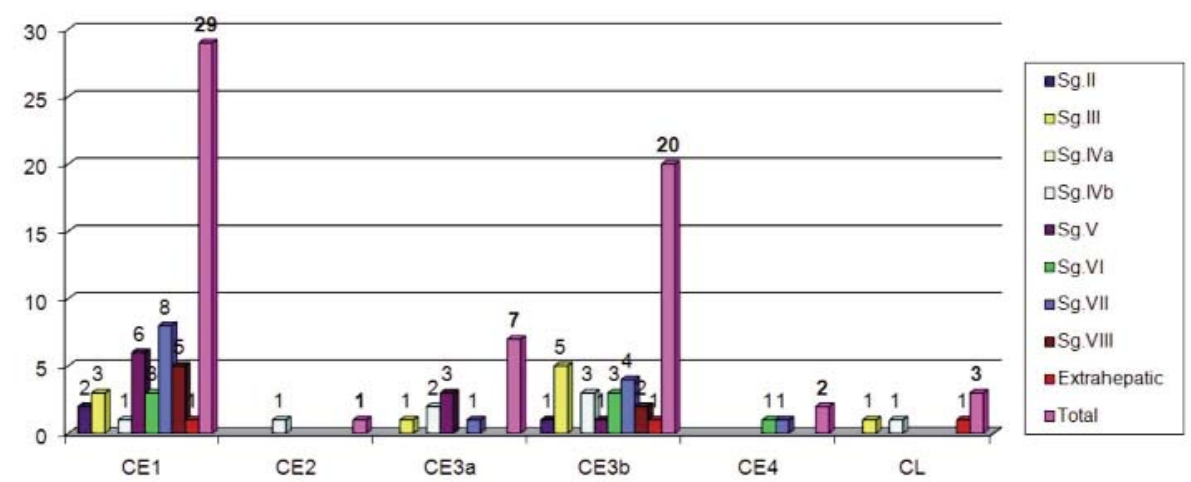

Graphic 2. Cysts distribution into the segments according the evolution stage

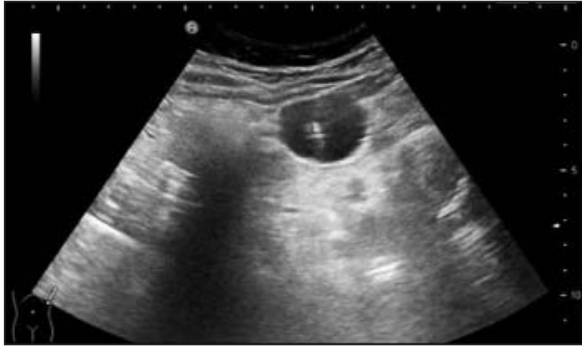

Figure 3. PAIR: punctioning the CE1 cyst

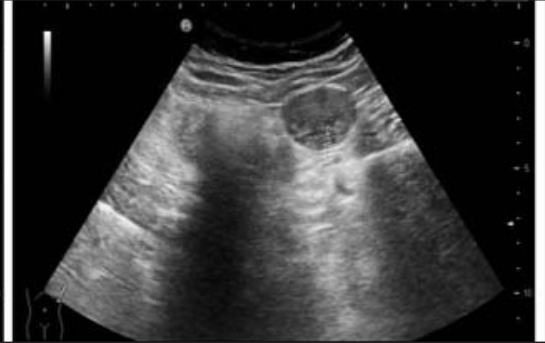

Figure 4. PAIR: the cyst is filled with $\mathrm{NaCl} 30 \%$

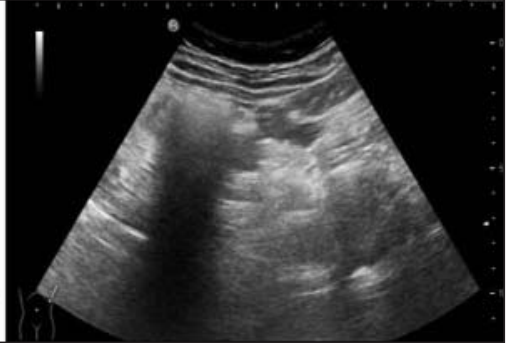

Figure 5. PAIR: the cyst is re-aspirated

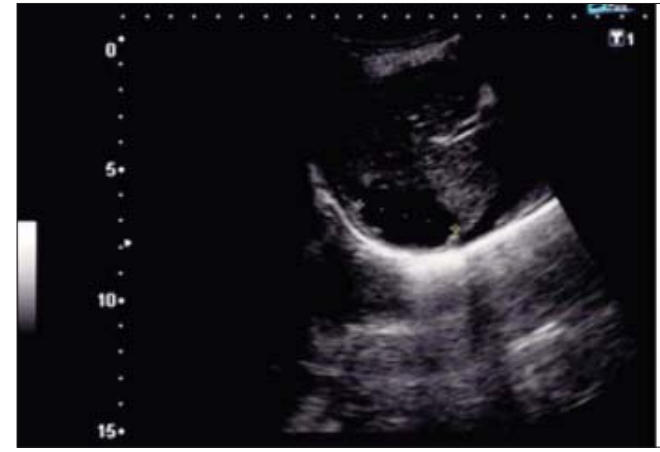

Figure 6. PAIR: after 3 months

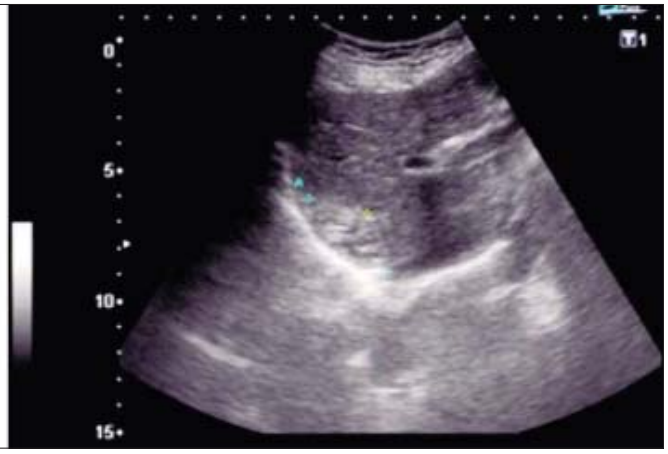

Figure 7. PAIR: after 2 years is performed (to be sure there is no biliary fistula), then this is aspirated too. The parasiticide compound $(\mathrm{NaCl} 30 \%)$ is injected and left in place for $9 \mathrm{~min}$, then is aspirated and the needle is retracted.

For CE2, CE3b type cysts, even CE3a and CE4 type cysts in selected cases, we performed Modified Catheterisation using a $14 \mathrm{Ch}$ pigtail catheter - Merit Medical locking drainage catheter 14F (Figs. 8-15). The first step is to puncture the cyst, under ultrasound guidance. A small amount of hydatid liquid is extracted by aspiration (note the type of the cyst, which doesn't allow to aspire much more), then the fluoroscopic compound is injected and the fluoroscopic control is performed. The guide wire is inserted, and the path is dilated using the kit dilators. Then the $14 \mathrm{Ch}$ pigtail catheter is inserted and an aggresive and effective lavage is performed, extracting the 


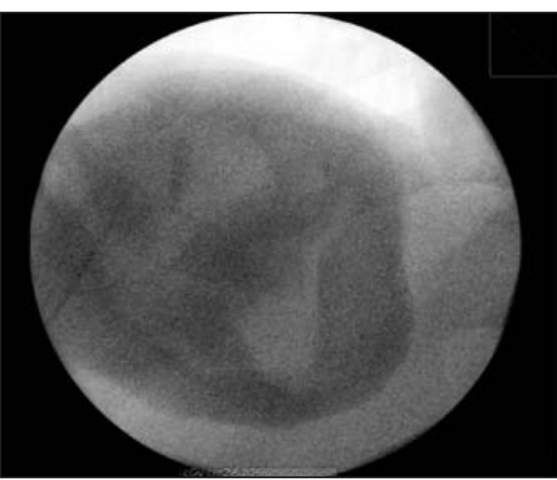

Figure 8. The CE3b cyst is punctioned

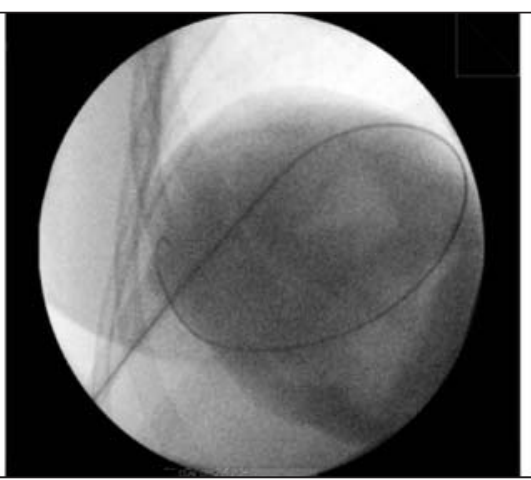

Figure 9. The guide wire is inserted

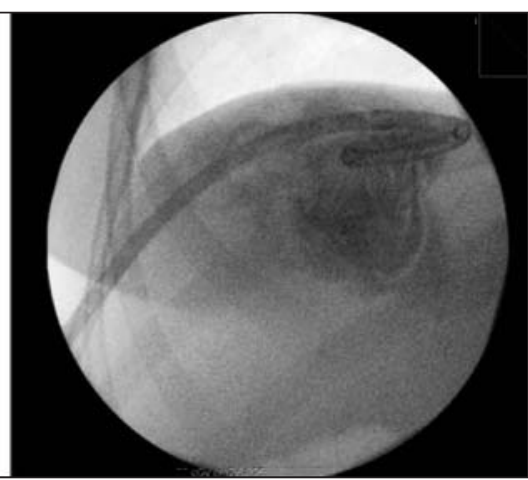

Figure 10. The 14Ch pigtail catheter

whole hydatid material within the cyst cavity using 96 alcohol for 9 min is performed. (magma ,liquid, vesiculae). After ultrasound If biliary flow is seen, the catheter is kept in and fluoroscopic control which shows the place till the biliary fistula would be closed, complete evacuation, the catheter is left in then the alcool lavage is performed. Then the place; if there is no biliary flow, a lavage of the catheter is extracted.

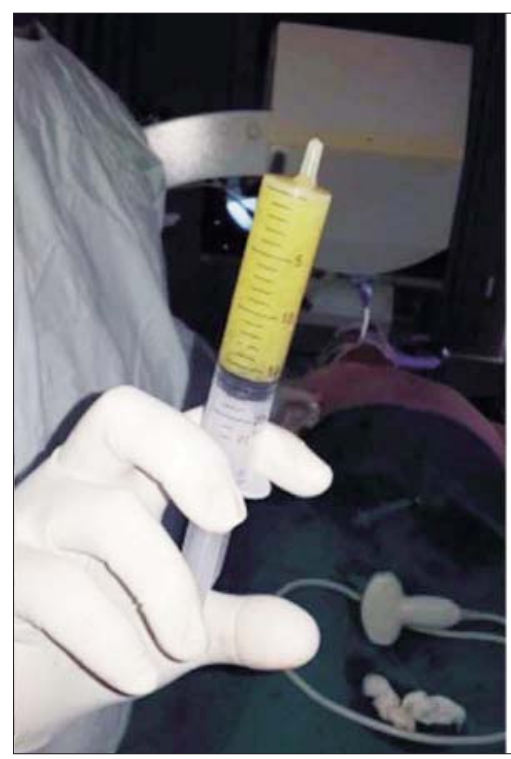

Figure 11. Cyst's content is extracted: liquid, magma, membranes
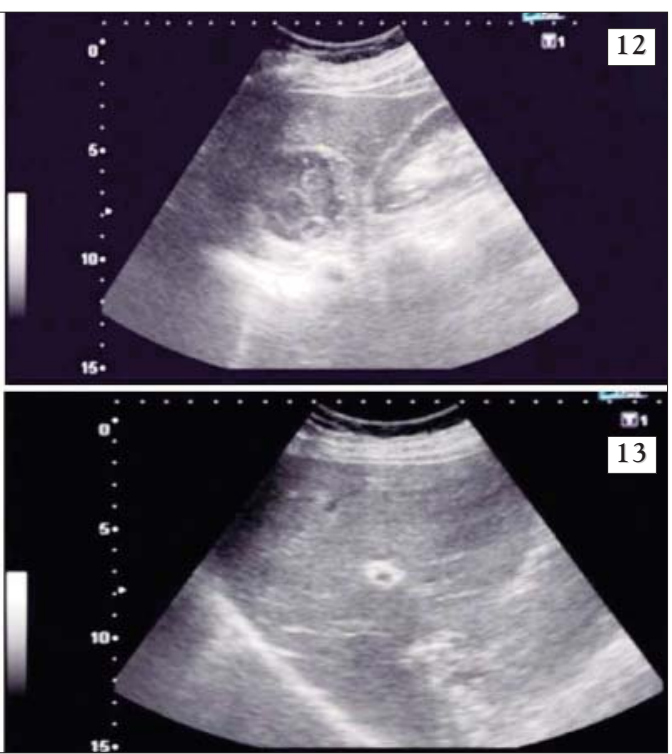

Figure 12. CE3b cyst at the beginning of the procedure Figure 13. At the end of MoCaT

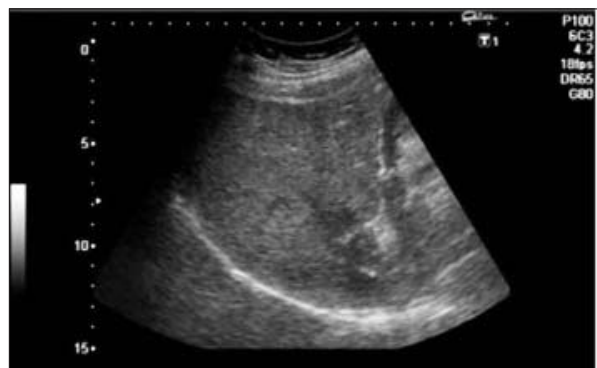

Figure 14. Control image after 1 year

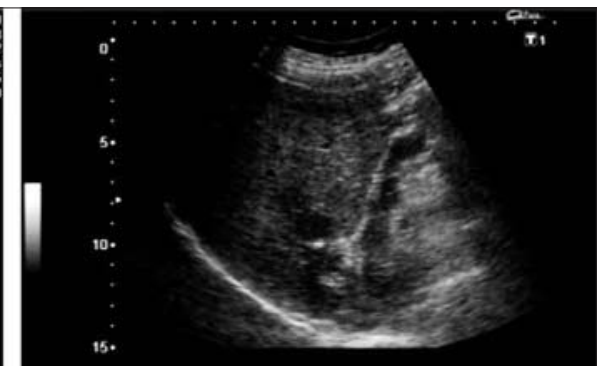

Figure 15. Control image after 1 year and 6 months 


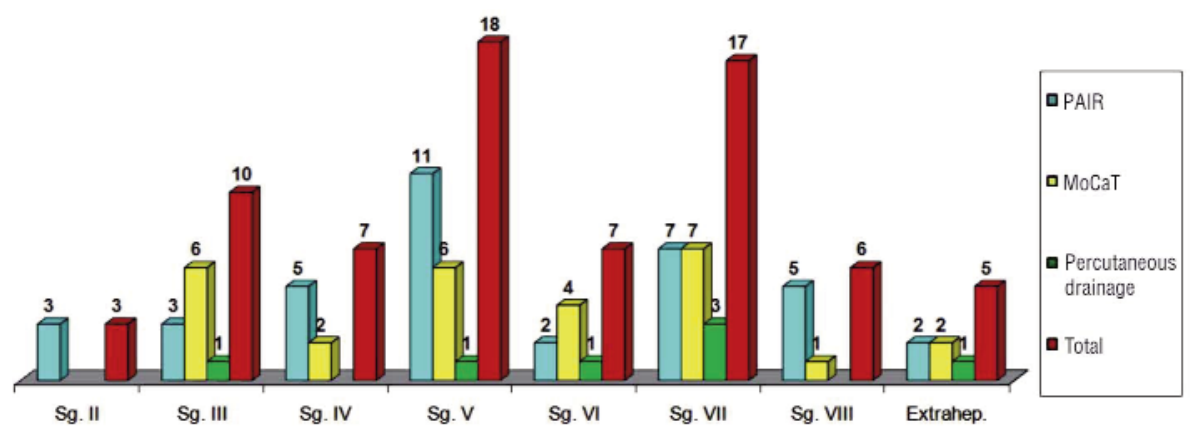

Graphic 3. The use of minimally invasive techniques according the cysts location

As parasiticide compound, 30\% sterile saline solution $(\mathrm{NaCl})$ or $96^{\circ}$ alcohol were used, according the technique. Both types of minimally invasive procedures (PAIR and MoCaT) could be used no matter the location of the cysts. The single condition to choose a technique was the stage of the cyst (Graphic 3).

\section{Results}

The evolution of the patients was favorable, and the surveillance was 2 years postintervention at least. There were no major surgical adverse effects. Mortality was 0 . We defined as an expected result obtaining a scar lesion or a small cavity with calcified walls (hyperechoic) (Figs. 6-7, 12-15, 16-20).

In 6 cases who underwent MoCaT procedure $(21,43 \%)$, a persistent colection of the residual cavity has been developed, which has been drained percutaneously. The catheter was left in place for 2 to 7 days. The MoCaT drainage was used to treat 5 residual cavities after PAIR $(13,16 \%)$, which didn't shrink after 1 year, due a biliary fistula. In those case, the dead proligerous membrana, which has been

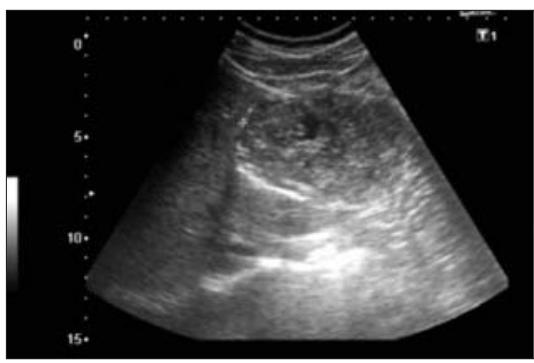

Figure 16. CE3b cyst in the $\mathrm{III}^{\text {rd }}$ segment

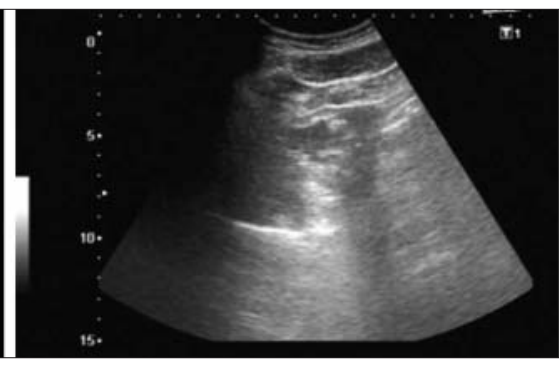

Figure 17. The cyst at the end of MoCaT procedure

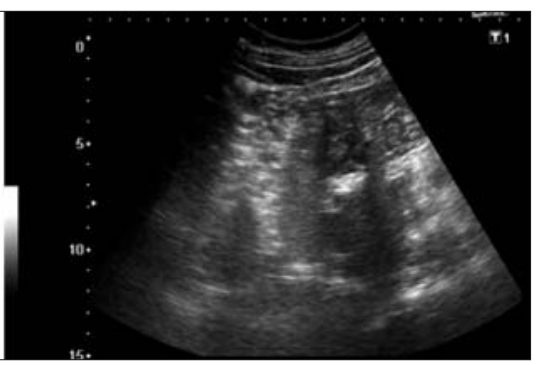

Figure 18. The scar after 3 months

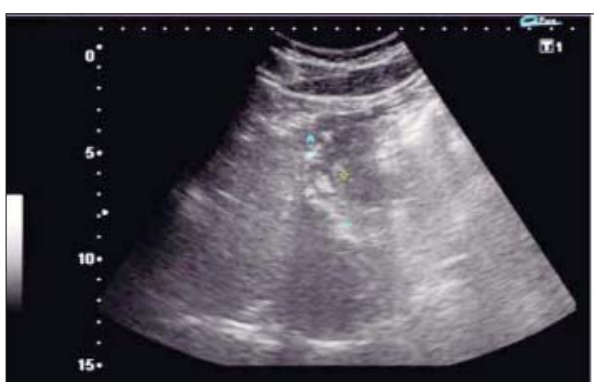

Figure 19. The scar after 6 months

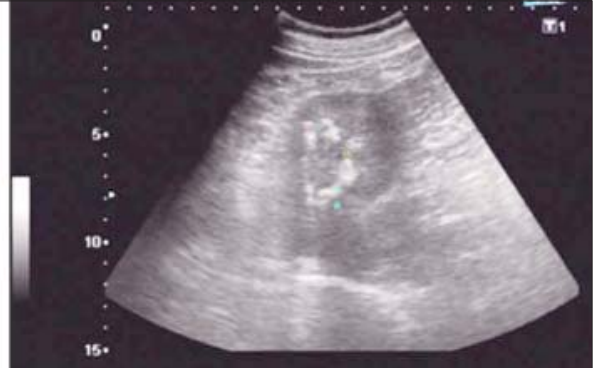

Figure 20. The scar after 15 months 
detached and fallen on the bottom of the cyst, could be evacuated, too. The results were also favorable.

Only $2(3,9 \%)$ patients needed conversion to open surgery. One patient had a cyst which had a tough wall which could not be penetrated by the catheter's tip. The other patient suffered a severe anaphylactic shock during a PAIR procedure for a CE1 large cyst; the procedure was ceased, and the medical team decided after the remission of this complication to convert it to open surgery. In both cases, partial pericystectomy (de - roofing the cyst and removing the dome of the cyst as much as possible), cystectomy and drainage (Lagrot procedure) was performed.

The lenght of hospitalisation was 3-4 days for patients who underwent PAIR technique, and 6 - 22 days for those who underwent MoCaT technique.

The patients have been under our surveillance at least 2 years after the minimally invasive procedures.

The complications (Table 1) we have faced during the treatment of $\mathrm{CE}$ using the minimally invasive techniques were represented by the cystic-biliary fistula in 15 cases $(29.4 \%)$ and the re-opening of the cyst's cavity in 11 cases (21.67\%). The low debit fistulae, which were the most, closed under conservative treatment; those which had a debit over $500 \mathrm{ml} /$ day needed endoscopic sphyncterotomy (3 cases). They are a complication which belongs to the cyst's stage (CE2, CE3a,b, CE4), not to a specific technique. Re-opening of the cyst cavity was due to the accumulation of lymph, bile and leucocytes, having no clinical sign (pain, fever,

Table 1. Complications seen after using minimally invasive techniques for $\mathrm{CE}$

\begin{tabular}{lc}
\hline Complication & Incidence \\
\hline Refilling the cavity & $11(21,67 \%)$ \\
\hline Biliary fistula / fistulae which needed SE & $15(29,4 \%) / 3$ \\
\hline Anaphyilactic shock & 2 \\
\hline Conversion to open surgery & 2 \\
\hline Bleeding & 0 \\
\hline Intracavitary Abscess & 0 \\
\hline Colangitis & 0 \\
\hline Cutaneous Rush & 4 \\
\hline Association of minor signs (rush, hTA, fever) & 1 \\
\hline
\end{tabular}

jaundice, etc.). This was a complication linked directly to the our technique. All these patients needed percutaneous drainage which solved this complication. This drainage was left in place for 3-5 days, then it was removed after ultrasound control.

\section{Discussion}

For every invasive technique used in the treatment of $\mathrm{CE}$, the rule is to associate albendazole $800 \mathrm{mg}$ per day for at least 1 week before and 1 month after the procedure (22-24). The romanian experience (Crețu and al.) advocates 3 and even 6 months post-procedural (17). Applying this recomendation, the risk of relapse is highly reduced.

The question if the percutaneous treatment is safe and effective was debated in many articles at the late '90 and early 2000, especially for PAIR technique. Especially associated with albendazole, PAIR is a good option for CE1 and even CE3a cysts $(23,25-27)$. The rate of complications was comparable: $28.8 \%$ for Men et al. (25), who counted also the cyst-biliary fistulae. On the other hand, in a larger number of patients, Kahriman et al. counts only perihepatic hemorrhage, cavity infection, anaphylaxis and allergic reactions, thus he declares only $6,3 \%$ complications; the cyst-biliary fistulae are not described. If we consider the same categories, there were only 6 cases (anaphylaxis - 2, allergic reactions - 4), and our percent should be $11,8 \%$.

As a newer procedure, Akhan's Modified Catheterisation (MoCaT) results were introduced in 2014 and 2017. On a cohort of 75 cysts, CE2 and CE3b type, Akhan et al. said that MoCaT is associated with a lower recurrence rate than other techniques, therefore it appears to be safe, reliable and efficient alternative" (20, 28). The indication to use minimally invasive techniques in treatment of CE has dramatically changed during the last 10 years. In 2008, in a state-of-art article on CE, Junghanss and al. recognised PAIR as a good and large used technique for CE1 and CE3a cysts, but defined the "non-PAIR percutaneous techniques” for CE2 and CE3b cysts as „rarely practiced”; 
instead, they advocated surgery (14). In 2010 Brunetti and al. put both percutaneous treatment and surgery as options in treatment of CE for CE1,2,3a and 3b stages (6). In 2015, Menezes da Silva repeated those indications, but the percutaneous treatment is written first at every stage of CE (29).

We believe the minimally invasive techniques PAIR and MoCaT are indeed effective and safe methods of treatment, being performed quite easily. Their results are good and invite us to use them as the first choice; the role of the open surgery remains for those cases with severe complications. The problematic evolution of the remaining cavities could be solved with the minimally invasive techniques. It is very important to emphasise that minimally invasive techniques could approach any cyst, no matter the location. They are also the least aggresive techniques regarding the abdominal wall damage.

\section{Conclusions}

1. The percutaneous treatment of $\mathrm{CE}$ is safe and effective, following the correct assignation of CE1, CE2, CE3a and $b$ and selected cases of CE 4 type cysts.

2. The percutaneous treatment of $\mathrm{CE}$ is an easier alternative to the open surgery.

3. Percutaneous techniques have lower rate of complications and relapses, and a shorter hospitalisation.

4. Once experimental, now routine, they become slighty the first option for invasive treatment of $\mathrm{CE}$.

5. The role of open surgery is restricted to $\mathrm{CE}$ with severe complications.

\section{Aknowledgement}

We want to thank Professor Okan Akhan from "Hacettepe" University - Faculty of Medicine, Ankara, our partner in the European project Heracles, who has trained us in using these minimally invasive technique.

\section{Conflict of Interest}

The authors declare no conflicts of interests.

\section{Author's Contributions}

All authors have equal contribution.

\section{References}

1. Kern P, Menezes da Silva A, Akhan O, Müllhaupt B, Vizcaychipi KA, Budke C, et al. The Echinococcoses: Diagnoses, Clinical Management and Burden of Disease. Adv Parasitol. 2017;96:259-369.

2. Ammann RW, Eckert J. Echinococcus. Gastroenterol Clin North Am. 1996; 25(3):655-89.

3. Zargar SA, Khuroo MS, Khan BA, Dar MY, Alai MS, Koul P. Intrabiliary rupture of hepatic hydatid cyst: sonographic and colangiographic appearances. Gastrointest Radiol. 1992;17(1):41-5.

4. Kornaros SE, Aboul-Nour TA. Frank intrabiliary rupture of hydatid hepatic cyst: diagnosis and treatment. J Am Coll Surg. 1996;183(5):466-70.

5. Akhan 0, Ozmen MN, Dincer A, Goçmen A, Kalyoncu F. Percutaneous treatment of pulmonary hydatid cysts. Cardiovasc Intervent Radiol. 1994; 17(5):271-5.

6. Brunetti E, Kern B, Vuitton DA. Expert consensus for the diagnosis and treatment of cystic and alveolar echinococcosis in humans. Acta Trop. 2010;114(1):1-16.

7. Siracusano A, Bruschi F. Cystic echinococcosis: progress and limits in epidemiology and immunodiagnosis. Parassitologia. 2006;48(1-2):65-6.

8. Ito A, Craig PS. Immunodiagnostic and molecular approaches for the detection of taeniid cestode infections. Trends Parasitol. 2003;19(9):377-81.

9. Siles-Lucas MM, Gottstein BB. Molecular tools for the diagnosis of cystic and alveolar echinococcosis. Trop Med Int Health. 2001;6(6):463-75.

10. Akisu C, Delibas SB, Bicmen C, Ozkoc S, Aksoy U, Turgay N. Comparative evaluation of western blotting in hepatic and pulmonary cystic echinococcosis. Parasite. 2006;13(4):321-6.

11. Khabiri AR, Bagheri F, Assmar M, Siavashi MR. Analysis of specific IgE and IgG subclass antibodies for diagnosis of Echinococcus granulosus. Parasite Immunol. 2006;28(8):357-62.

12. WHO-Informal Working Group on Echinococcosis. International classification of ultrasound images in cystic echinococcosis for application in clinical and field epidemiological settings. Acta Trop. 2003;85(2):253-61.

13. Gharbi HA, Hassine W, Brauner MW, Dupuch K. Ultrasound examination of the hydatic liver. Radiology. 1981;139(2):459-63.

14. Junghanss $T$, da Silva AM, Horton J, Chiodini PL, Brunetti E. Clinical management of cystic echinococcosis: state of the art, problems, and perspectives. Am J Trop Med Hyg. 2008;79(3): 301-11.

15. Hosch W, Stojkovic M, Janisch T, Kauffmann GW, Junghanss T. The role of calcification for staging cystic echinococcosis (CE). Eur Radiol. 2007;17(10):2538-45. Epub 2007 May 1.

16. Arif SH, Shams UIB, Wani NA, Zargar SA, Wani MA, Tabassum R et al. Albendazole as an adjuvant to the standard surgical management of hydatid cyst liver. Int J Surg. 2008;6(6):448-51.

17. Crețu CM, Codreanu RR, Mastalier B, Popa LG, Cordoș I, Beuran $\mathrm{M}$, et al. Albendazole associated to surgery or minimally invasive procedures for hydatid disease - how much and how long. Chirurgia (Bucur). 2012;107(1):15-21

18. Ben Amor N, Margouri M, Gharbi HA. Treatment of hepatic hydatid cyst in sheep by echografic puncture. La Tunisie medicale. 1981;64(4): 325-31

19. Filice C1, Pirola F, Brunetti E, Dughetti S, Strosselli M, Foglieni CS. A new therapeutic approach for hydatid liver cysts. Aspiration and alcohol injection under sonographic guidance. Gastroenterology. 1990;98(5 Pt 1):1366-8. 
20. Akhan O, Erbahceci A, Akinci D, Islim F, Ciftci T, Akpinar B. Longterm results of percutaneous treatment of CE2/CE3b (Gharbi type III) liver hydatid cysts: a retrospective comparison study of three percutaneous techniques. 2014, Innovation for the Management of Echinococcosis, Besançon, 27-29 March; published in Parasite. 2014;21:28

21. WHO Informal Working Group on Echinococcosis \& World Health Organisation. Dept. of Epidemic and Pandemic Alert and Response. PAIR: Puncture, Aspiration, Injection, Re-Aspiration. An Option for the Treatment of Cystic Echinococcosis. 2001; WHO, Geneva (Technical documents).

22. Ustunsoz B, Akhan O, Kamiloglu MA, Somuncu I, Ugurel MS Cetiner S. Percutaneous treatment of hydatid cysts of the liver: long-term results. AJR Am J Roentgenol. 1999;172(1):91-6.

23. Smego RA, Bhatti S, Khaliq AA, Asim Beg M. Percutaneous aspiration-injection-reaspiration drainage plus albendazole or mebendazole for hepatic cystic echinococcosis: a meta-analysis. Clin Infect Dis. 2003;37(8):1073-83. Epub 2003 Sep 23.

24. Akhan 0 , Yildiz AE, Akinci D, Yildiz BD, Ciftci T. Is the adjuvant albendazole treatment really needed with PAIR in the management of liver hydatid cysts? A prospective, randomized trial with short-term follow-up results. Cardiovasc Intervent Radiol. 2014;37(6):1568-74.

25. Men S, Hekimoglu B, Yücesoy C, Serdar Arda I, Baran I. Percutaneous treatment of hepatic hydatid cysts: an alternative to surgery. AJR Am J Roentgenol. 1999;172(1):83-9.

26. da Silva AM, Vasconcelos Dias H, Iria I, Fonseca MA, Valente M. Cystic Echinococcosis in the Liver: Evaluation of Percutaneous Treatment. J Gastroent Hepat Research. 2015; 4-12;

27. Kahriman G, Ozcan N, Dogan S, Karaborklu 0. Percutaneous treatment of liver hydatid cysts in 190 patients: a retrospective study. Acta Radiologica. 2017; 58(6): 676-84

28. Akhan 0, Salik A, Ciftci T, Akinci D, Islim F, Akpinar B. Comparison of Long-Term Results of Percutaneous Treatment Techniques for Hepatic Cystic Echinococcosis Types 2 and 3b. AJR Am J Roentgenol. 2017;208(4):878-884.

29. da Silva AM. Cystic Echinococcosis in the Liver: Nomenclature and Surgical Procedures. J Surg Surgical Res. 2015;1(3):59-65. 